\title{
IMPLICATIONS FOR LOADING JURIDICAL LIABILITY RIGHTS UNDER POWER OF ATTORNEY MAKE HYPOTHEEK RIGHTS (SKMHT) PROCEDURAL DEFECTS
}

\author{
Riky Rustam $^{1}$, Rumi Suwardiyati ${ }^{2}$
}

\begin{abstract}
The credit agreement is an agreement in principal to followedby the additional treaty of guarantee. With regard to guarantees for immovable objects using mortgage rights. In banking practice related to credit agreements, it is inseparable from a power of attorney to impose mortgage rights (SKMHT). Those who have the authority to make the power of attorney are notaries. In making deeds in their daily lives, a notary is obliged to pay attention to the rules for making authentic deeds. Making authentic deeds must meet formal requirements, material requirements and external requirements in making them. If one of these conditions is not fulfilled, it can cause the deed to be degraded or decrease in the status of the deed, which was initially considered an authentic deed to become an underhand deed. In connection with the power of attorney imposing mortgage rights (SKMHT), Notaries who have cooperation with banks will make the power of attorney every day. It is possible that the number of deeds made makes the notary forget to sign the deed he has made. The signatures of the parties that are in the power of attorney already exist, but the signature of the Notary who ratifies the power of attorney is not there. This is possible until the Notary's death, the deed he has made has not been signed. If the Notary passes away and the deed he has drawn up has not been signed and a dispute arises, how will the deed be authenticated. The research objective is to analyze the authentication of the power of attorney to impose mortgage rights (SKMHT) that have not been signed by a notary public. The method used is juridical normative with a statutory approach and a conceptual approach. The conclusion of the research is that the notary of the SKMHT deed has not been signed by the notary until the Notary concerned dies, violating the formal requirements of the authentic deed This resulted in the power of attorney imposing mortgage rights (SKMHT) to be null and void by law while still giving the injured party the right to claim compensation from the Notary who had harmed the party.
\end{abstract}

Keywords: SKMHT, Minuta Deed, Notary

\section{The Introduction}

Discusses the credit agreement, also discusses the guarantee. Collateral not only serves to guarantee the repayment of debtor's debt, but guarantees also play a very important role in realizing the provision of credit to debtors. The term guarantee is a translation from the Dutch language zakerheid or cautie which covers in general the ways the creditor guarantees the fulfillment of the bill inadditionliability of the debtor to the generalfor the's goods (Salim HS, 2004: 21). Hartono Hadisoeprapto also argues that a guarantee is something that is given to a creditor to provide assurance that

\footnotetext{
${ }^{1}$ Fakultas Hukum Universitas Islam Indonesia, Email: rikyrustam@gmail.com

2 Fakultas Hukum Universitas Brawijaya, Email: rumisuwardiyati@ub.ac.id
} 
the debtor will fulfill an obligation that can be valued in money arising from an engagement (Salim HS, 2004: 22). Mortgage rights are regulated in several regulations, namely: (Harsono, 2005: 414).

a. Basic Agrarian Law Article 25, Article 33, Article 39 and Article 51 regarding Property Rights, Business Use Rights and Building Use Rights as objects of mortgage rights and orders for further regulation of mortgage rights by law.

b. Law Number 4 of 1996 concerning Mortgage Rights to Land and Objects Related to Land.

c. Government Regulation Number 24 of 1997 concerning Land Registration. d. Regulation of the State Minister for Agrarian Affairs / Head of BPN Number 3 of 1997 concerning Provisions for the Implementation of Government Regulation Number 24 of 1997 concerning Land Registration.

d. Regulation of the State Minister for Agrarian Affairs / Head of BPN Number 4 of 1996 concerning Determination of Time Limits for the Use of Power of Attorney to Impose Mortgage Rights to Guarantee Repayment of Certain Credits.

One of the guarantees or collateral that is known is Mortgage Rights. Article 1 point (1) of the 1996 Insurance Rights Law regarding the mortgage rights to Land and Objects Related to Land (hereinafter referred to as UUHT) states:

"Mortgage rights over land and objects related to land, hereinafter referred to as Hak Dependent, is a security right imposed on land rights as referred to in Law Number 5 of 1960 concerning the Basic Regulations of thegraria, including or not including other objects which are an integral part of the land, for the settlement of certain debts, which give a position that is give priority to certain creditors over other creditors".

From the definition of mortgage rights according to the UUHT provides several important elements of mortgage rights, namely: rights, namely guarantee rights; who is charged; on land, as referred to by Law No. 5/1960; the following or not with other objects which are an integral part of the land; to pay off certain debts; and giving priority to certain creditors over other creditors (Satrio, 1997: 65).

Granting of mortgage rights is carried out by parties who are the subject of mortgage rights, Article 8 and Article 9 of the Mortgage Rights Law stipulates that the subject of mortgage rights consists of two parties, namely: (Sutedi, 2010: 50).

a. The guarantor of the security right (the person or party that guarantees the object of the mortgage right), namely an individual or legal entity that has the authority to take legal actions against the object of the security right concerned, and the authority to take legal action against the object of the security right must rest with the right giver. dependents at the time of registration of mortgage rights. 
b. Holders of mortgage rights (people or parties who receive security rights as collateral for the receivables they give), namely individuals or legal entities that are the parties in the debt.

Thus, it can be concluded that basically the security right is a form of guarantee for repayment of debt, with pre-emptive rights, with the object of the guarantee in the form of Land Rights as regulated in Law Number 5 of 1960 concerning Basic rule of Agrarian points (Muljadi \& Widjaja, 2005: 13).

In granting mortgage rights, if for some reason the guarantor of the mortgage cannot appear before PPAT to grant mortgage rights, the guarantor of the mortgage right is obliged to appoint another party to be his proxy in granting the security right by providing a Power of Attorney to impose a security right (which is generally abbreviated as SKMHT) in the form of an authentic deed. Making a Power of Attorney Imposing Mortgage Rights can be requested to the Notary or the PPAT (Rustam, 2017: 202).

Preparation of SKMHT which is done before a Notary is based on the provisions of Article 15 paragraph (1) of the Law on Mortgage which authorizes the Notary to make SKMHT. As an authentic deed, SKMHT made by a notary is not a deed that can be made entirely based on the wishes of the parties and the principle of freedom of contract only. This deed must also take into account the forms and procedures that have been stipulated by law as stipulated in Law Number 30 of 2004 concerning the Position of Notary Public (hereinafter referred to as Law on the Position of Notary Public) and Law Number 02 of 2014 concerning Amendments Number 30 Year 2004 concerning Notary Position (hereinafter referred to as Amendment Notary Position Law) as a guideline for notaries in carrying out their obligations and powers (Adjie, 2008: 45).

One of the obligations that must be followed by a notary in this case is the obligation to prepare a minimum SKMHT deed issued by the notary. As stipulated in Article 16 paragraph (1) letter b of the Law on the Position of Notary Public, it states that in carrying out his / her office, Notary Public is obliged to make deeds in the form of Minutes of Deed and keep it as part of the Notary Protocol. Complementing this matter, Article 1 point (8) of the Law on the Position of Notary Public provides a definition that Minuta Deed is the original deed containing the signatures of the parties, witnesses and Notaries, which are kept as part of the Notary Protocol.

In practice, it is often found that a deed whose copy has been signed by a notary and given to the parties, the Minuta Deed which should have also been signed by the Notary is only signed by the parties and witnesses, while the notary concerned has not signed the Minuta deed. the. This was also found in the minutes of deeds which were SKMHT minutas made by notaries. The main problem that occurs is that the minuta deed has not been signed by the notary even until the notary concerned has passed away. On the other hand, a copy of the unsigned SKMHT of the minuta has been used to impose mortgage rights and the mortgage itself has been born and binds the parties in it.

Having not signed the minimum SKMHT by the notary will of course have an impact on the SKMHT that has been used by the parties to impose mortgage rights. The occurrence of procedural defects like this will be detrimental to the parties, especially creditors. If this procedural error results in the cancellation of the mortgage that is charged, automatically the position 
of the creditor will become a concurrent creditor who does not have a debt repayment guarantee and also does not have the privilege to take precedence in repaying debtor's debt. On the other hand, if forced to make re-mortgage rights, of course it will be an additional expense for the parties that they shouldn't have to pay.

Therefore, the problem that needs to be studied in depth in this research is the SKMHT authentication which is the basis for the parties in imposing the security rights. The unclear SKMHT authentication used, of course, will also have an impact on the validity of the security rights that have been charged and also for interested parties. Does not signing the minimum SKMHT will cause the deed to be lost or will the deed even be null and void.

\section{Research methods}

The method used is juridical normative with a statutory approach and a conceptual approach. The juridical normative research method is library law research conducted by examining library materials or secondary data (Soekanto \& Mahmudji, 2003: 13). Thus, the data used is secondary data consisting of primary legal materials, secondary legal materials and tertiary legal materials.

\section{Discussion and Results}

Of a power of attorney to impose a mortgage (SKMHT) is the power given by the party granting the mortgage as the authorizer to the recipient of special power to charge an object with a mortgage (Adhi et al., 2013). Article 1 paragraph (1) Government Regulation Number 37 of 1998 concerning Land Deed Making Officials provides a meaning related to the Power of Attorney to Impose Mortgage Rights, namely a special power of attorney to grant or impose mortgage rights only. The function of SKMHT itself is as a substitute if the guarantor of the mortgage rights cannot appear before the PPAT.

The authority to make SKMHT is not only with the Notary but also with PPAT, SKMHT can be made with a notary deed or PPAT deed, both deeds made by Notary or Notary are authentic deeds (Usman, 2018). This is also contained in the provisions of Article 15 paragraph (1) of the Mortgage Rights Law. Apart from that, in making it must refer to Article 96 paragraph (1) PMNA / PerKaban Number 3/1997 as amended by PerKaban No 8/2012 and also the requirements for making a Notary deed.

There are 2 ways for the parties to charge the mortgage rights, namely first the mortgage provider comes directly to the PPAT to sign the Deed of Assignment (APHT), or the second charges the Mortgage Rights using SKMHT. The second way is done if the mortgage provider is unable to appear in person before the PPAT (Wiguna, 2017).

There are 2 (two) reasons for using SKMHT, namely: first, Subjective reasons, including: granting of mortgage rights cannot appear alone before a notary / PPAT to make a deed of mortgage, long or long mortgage procedure, the cost of using mortgage rights is quite high, credit provided is short term, the credit is not big or small, and the debtor is very trustworthy. Second, Objective reasons, including: Certificate not issued, the land transfer has not been implemented, land splitting or merging has not been completed in the name of the owner of the mortgage right, and roya hasn't done yet (Salim, 
2004: 119).

Power of Attorney to Impose Mortgage Rights (SKMHT) is one of the authentic facts that can be made before the Land Deed Officer (PPAT) or before a Notary. Subekti stated that an authentic deed is evidence that is "binding", in the sense that what is written in the deed must be trusted by the judge, that is, it must be considered as true as long as its untruth is not proven (Kohar, 1983: 73). Article 1868 of the Penal Code also provides the meaning that authentic deed is a deed made in the form determined by law by/or in front of a public official who is authorized for that purpose, at the place where the deed was made.

Basically, an authentic deed does not only depend on the validity of the agreement as regulated in Article 1320 of the Criminal Code, but must also comply with the formal requirements regulated by statutory regulations. The Amendment Law of Notary Position provides that authentic deeds must be made in the presence or by a public official, in the presence of witnesses and witnesses, accompanied by a reading by a notary public and immediately signed afterwards (Kohar, 1983: 25), as well as actions required by this law must be stated in deed.

Authentic deeds must be drawn up in the presence or by a public official. The word "in front of" indicates that the deed was made at the request of someone, while the meaning of the deed made "by" a public official shows that the deed was made because of an incident, examination, decision, and so on (Kie, 2007: 442). Meanwhile, the official in this case must be authorized for that purpose at the place where the deed was drawn up.

The authority of a Notary to make an authentic deed is determined by Article 15 of the Law on Amendment of Notary Public, which stipulates that: "Notaries are authorized to make authentic Deeds regarding all actions, agreements, and stipulations required by statutory regulations and/or desired by those concerned. to be stated in an authentic Deed, guarantee the certainty of the making date of the Deed, keep the Deed, provide grosse, copy and excerpt of the Deed, all of that as long as the making of the Deed is also not assigned or excluded to other officials or other people as stipulated by law".

As an authentic deed, SKMHT made by a Notary must comply with the format and form determined by the prevailing laws and regulations. Article 38 of the Law on the Position of Notary Public states that: Each Deed consists of the beginning of the Deed or the head of the Deed, Deed bodies and end or closing of the Deed. The beginning of the Deed or the head of the Deed contains title Deed, deed number; hour, day, date, month and year; and full name and domicile of the Notary. The Deed Body contains: full name, place and date of birth, nationality, occupation, position, position, residence of the actors and / or the person they represent; information regarding the position of acting against; the contents of the Deed which constitute the will and desire of the interested parties; and the full name, place and date of birth, as well as occupation, position, position and place of residence of each of the identifying witnesses. The end or closing of the Deed contains: a description of the reading of the Deed as referred to in Article 16 paragraph (1) letter $\mathrm{m}$ or Article 16 paragraph (7); a description of the signing and place of signing or translation of the Deed, if any; full name, place and date of birth, occupation, position, position and place of residence 
of each witness to the Deed; and d. a description of the absence of changes that have occurred in the making of the Deed or a description of any changes which may be in the form of additions, deletions or replacements as well as the number of changes thereof. The Deed of Notary Public and Temporary Officer of Notary Public, apart from containing the provisions as referred to in paragraph (2), paragraph (3) and paragraph (4), also contains the number and date of the appointment, as well as the official who appointed it.

The provisions of Article 38 of the Amendment Notary Position Law are then complemented by sanctions as stipulated in Article 41 of the Amendment Notary Law which determines that "Violation of the provisions as referred to in Article 38, Article 39, and Article 40 results in the Deed only having the power of proof as deeds. under hand ". More fully, Article 50 paragraph (5) of the Law on the Position of Notary Public states that:

"In the case of the provisions referred to in paragraph (1), paragraph (2), paragraph (3), and paragraph (4), as well as in Article 38 paragraph (4) letter $d$ is not fulfilled, the Deed only has the power of proof as an underhand deed and can be an excuse for the party suffering a loss to demand reimbursement of expenses, compensation and interest from the Notary".

In addition to the form of the deed which has been expressly stipulated by Article 38 of the Law on the Position of Notary as mentioned above, to ensure the authenticity of a Notary deed it also has several obligations that must be carried out. As stipulated in Article 16 of the Amendment Notary Position Law, it is stated that:

1. In carrying out his / her office, a Notary is obliged to:

a. Acting trustworthy, honest, thorough, independent, impartial, and safeguarding the interests of parties involved in legal actions;

b. Making deeds in the form of deeds and keeping them as part of the notary protocol;

c. Affix letters and documents as well as fingerprints of the applicants on the deed of minuta;

d. Issuing the grosse deed, a copy of the deed, or an excerpt of deed based on the minuta deed;

e. Providing services in accordance with the provisions of this law, unless there is a reason to refuse it;

f. Keep everything concerning the deed he has drawn and all information obtained for the making of the deed in accordance with the oath / promise of office, unless the law stipulates otherwise;

g. Binding the deeds that he makes in 1 (one) month into a book containing no more than 50 (fifty) deeds, and if the number of deeds cannot be contained in one book, the deeds can be bound into more than one book, and record the minuta deeds., month, and year of manufacture on the cover of each book;

h. Make a list of deeds of protest against non-payment or non-receipt of securities;

i. Make a list of deeds relating to wills according to the time sequence of deeds making each month; 
j. Send the list of deeds as referred to in letter i or the nil list relating to wills to the center of the will of the ministry that administers governmental affairs in the legal sector within 5 (five) days in the first week of each following month;

$\mathrm{k}$. Record in the repertorium the date of delivery of the testament at the end of each month;

1. Has a stamp or stamp bearing the symbol of the Republic of Indonesia and in the space surrounding it is written the name, position and domicile of the person concerned;

$m$. Read out the deed in front of the audience in the presence of at least 2 (two) witnesses, or 4 (four) special witnesses for the making of the will under hand, and signed on the spot by the tappers, witnesses and notary public; and

n. Receiving internship for prospective notaries.

2. The obligation to keep the Minuta Deed as referred to in paragraph (1) letter b does not apply, in the case of the Notary issuing the Deed in originali.

3. Deed in originali as referred to in paragraph (2) includes:

a. Deed of payment of rent, interest, and pension;

b. Cash payment offer deed;

c. Deed of protest against non-payment or non-receipt of securities;

d. Power of attorney;

e. Certificate of ownership; and

f. Other deeds in accordance with the provisions of laws and regulations.

4. Deed in originali as referred to in paragraph (2) can be made more than 1 (one) duplicate, signed at the same time, form and content, provided that each Deed is written with the words "APPLY AS ONE AND ONE APPLICABLE. FOR ALL".

5. Deed in originali containing the power of attorney which has not been filled in with the name of the authorized person can only be made in 1 (one) copy.

6. The shape and size of the stamp or stamp as referred to in paragraph (1) letter 1 shall be stipulated by the Regulation The Minister.

7. Reading the Deed as referred to in paragraph (1) letter $\mathrm{m}$ is not obligatory if the actor wants the Deed not to be read because the viewer has read, knows, and understands its contents, provided that it is stated in the closing of the Deed as well as in the each page of the Minuta Deed is initialed by the audience, witnesses, and Notary.

8. The provisions as referred to in paragraph (7) are exempted from reading the head of the Deed, comparison, brief explanation of the Deed's principal d clear, as well as the closing of the Deed.

9. If one of the conditions as referred to in paragraph (1) letter $\mathrm{m}$ and paragraph (7) is not fulfilled, the Deed concerned only has the power of 
proof as an underhand deed.

10. The provisions as referred to in paragraph (9) do not apply to making a will.

11. Notaries who violate the provisions as referred to in paragraph (1) letter a to letter 1 may be subject to sanctions in the form of:
a. written warning;
b. temporary dismissal;
c. honorific dismissal; or
d. dishonorable discharge.

12. Apart from being subjected to the sanctions as referred to in paragraph (11), violation of the provisions of Article 16 paragraph (1) letter $\mathrm{j}$ can be an excuse for the party suffering a loss to demand reimbursement of expenses, compensation and interest from the Notary.

13. Notary who violates the provisions as referred to in paragraph (1) letter $\mathrm{n}$ may be subject to sanctions in the form of a written warning.

Article 16 paragraph (1) letter b of the Law on Notary Position above explicitly requires Notaries to make a minimum deed for each deed he makes. The obligation to make the minimum deed can be waived if the Notary makes the deed in the form of deed in originali as referred to in paragraph (2) of the same article. Followed by Article 16 paragraph (3) of the Law on the Position of Notary Public, it is determined that the Deed in originali includes: Deed of payment of rent, interest, and pension; Deed of offering cash payment; A deed of protest against non-payment or non-receipt of securities; Power of attorney; Certificate of ownership deed; and Other deeds in accordance with the provisions of laws and regulations.

If based on the provisions of Article 16 of the Law on the Position of Notary Public of this change, not making Minuta Deed by the Notary will result in the Notary being sanctioned as stipulated in paragraph (11) of the article which determines that "Notary who violates the provisions referred to in paragraph (1) letter a up to letter 1 may be subject to sanctions in the form of: Written warning; Temporary suspension; Dismissal with respect; or Disrespectful dismissal.

The provisions of Article 16 of the Law on the Position of Notary Public are also strengthened by the provisions of Article 58 paragraph (1) of the Law on Notary Office which stipulates that "Notaries make a list of deeds, a list of letters under the legalized hand, a list of under-handed letters that are recorded, and a list of other letters that are required by this Law ", and also Article 59 paragraph (1) which stipulates that" Notaries make a clapper list for a list of deeds and a list of letters under the hands of legalized as referred to in Article 58 paragraph (1), arranged alphabetically and done every month ".

Notary deeds must be viewed in two aspects, namely material aspects and formal aspects. The material aspect is that everything contained in the notary must be considered correct as a statement or statement of a notary in the deed of relaas, and must be assessed as a statement or statement of the parties in the deed of party, and must have certain limitations. Determining such limits depends on what is seen, heard by the Notary or stated, explained 
by the parties before the Notary Public.

In material terms, the contents of the deed are the wishes of the parties, but under certain circumstances or for certain reasons the deed may become null and void if the material of the deed is contrary to the prevailing laws and regulations. In material terms, the notary deed has no power of execution and is null and void by a court decision, if the notary deed contains the following: Contains more than 1 (one) legal action or legal action; The material of the deed contradicts the law governing the said act or legal action (Adjie, 2009: 139).

An authentic or legally flawed deed must be determined by proof. This proof can be done in several aspects, namely outward proof, formal proof and material proof (Suwardiyati, 2017).

Outward proof teaches that the evidentiary value of a notary's deed must be seen as it is without the need to be contradicted by other evidence. If there is a party who judges that a notarial deed does not meet the requirements as an authentic deed, then the person concerned is obliged to prove that the deed is physically not an authentic deed. Evidence of denial or physical denial of the notary deed must be based on the requirements of the notary deed as an authentic deed and must be filed through a lawsuit against the court.

In Formal proof, the notary deed must provide certainty about an event and facts in the deed that have actually been experienced, witnessed and seen by the notary or explained by the parties facing him. Formally, the deed aims to prove the truth and certainty of the day, date, month, year, time before and the parties who are present, initials and signatures of the parties, witnesses and notaries. If the formal aspect is disputed by the parties, the parties must prove the formality of the notary deed. If it is not proven, then the deed must be accepted by anyone related to the deed.

Material proof determines that everything in the deed is valid evidence against the parties who made the deed or those who get rights and apply to the public, unless there is evidence to the contrary. The information or statement stated in the official deed or the deed of the party must be deemed correct, which is then included in the deed so that it acts as true. If it turns out that the statements / statements of the parties are not true, then this is the responsibility of the parties themselves. Based on these matters, the contents of the notary deed have certainty as to be true so that it becomes valid evidence for the parties as well as the rights recipients of the deed made. If there is a party denying the material aspects of the notarial deed, that party must prove that what is explained or stated in the deed is not the real thing.

The three aspects of proof above are the perfection of a notary deed as an authentic deed. If one of the three aspects is not true, then the relevant deed is degraded as a deed that has the power of proof of the deed under hand or is null and void based on a court ruling.

The notary is not only on duty until the deed he has drawn up is signed and a copy is given to the parties. But the notary must also be responsible for the deed for the rest of his life, as long as the world of Indonesian notaries still exists and is not dissolved, this is because as long as that is the juridical age of the notary deed (Suwardiyati, 2017). 
Further regarding the obligation of notaries in making and signing Minutas of Deeds, Article 44 of the Amendment of the Notary Position Law stipulates that:

1. As soon as the Deed is read, the Deed is signed by each of the parties, witnesses, and Notary, unless there is an audience who cannot. put a signature stating the reason.

2. The reasons as referred to in paragraph (1) shall be clearly stated at the end of the Deed.

3. The deed as referred to in Article 43 paragraph (3) shall be signed by the tappers, notaries, witnesses and official translators.

4. The reading, translation or explanation, and signing as referred to in paragraph (1) and paragraph (3) as well as in Article 43 paragraph (3) shall be stated expressly at the end of the Deed.

5. Violation of the provisions as referred to in paragraph (1), paragraph (2), paragraph (3), and paragraph (4) results in a Deed only having the power of proof as an underhand deed and may become an excuse for the party suffering losses. to demand reimbursement of expenses, compensation and interest from the Notary.

The provisions of Article 44 of the Amendment of the Notary Position Law above reinforce the sanctions for not signing the Minuta Deed. Although it does not explicitly mention the signing of the Minuta Deed, these provisions clearly require the Notary to sign the Minuta Deed. As in Article 44 paragraph (1) of the Notary Position Law which reads "As soon as the Deed is read, the Deed is signed by every actor, witness, and notary public, except if there is an audience who is unable to sign with stating the reason", the phrase "Immediately after the Deed is read out. "Indicates that what is signed is the Minuta Deed, because the Minuta Deed itself is the original Deed which includes the signatures of the parties, witnesses and Notaries, which are kept as part of the Notary Protocol.

Article 44 paragraph (5) of the Amendment Notary Position Law imposes sanctions for violating the provisions of Article 44 of the Amendment Notary Law, namely that the Minuta SKMHT Deed which is not signed by a Notary until death will result in the deed being drawn up no longer having the status of an authentic deed., instead, it turns into a deed with evidence under hand or in other languages as well as a deed under hand. The loss of SKMHT's position as authentic deed will also cause the SKMHT to be null and void. This is the result of not fulfilling the formal requirements that must be met in an SKMHTin Article as stipulated15 of the Mortgage Rights Law.

On the other hand, all the provisions that must be met in the preparation of an authentic deed above are the formal requirements of an authentic deed. A deed that is made which does not comply with the procedures stipulated in the Law on the Position of Notary Public, will result in the deed becoming a deed that does not meet the formal requirements of an agreement. The formal terms of the agreement are special conditions that are regulated by law and all the formalities must be fulfilled, where if these conditions are not fulfilled it will result in the agreement being null and void (Subekti, 1984: 25). Based on the description above, it can be concluded that 
by not signing the Minuta SKMHT by a notary, this has violated the formal requirements of an authentic deed based on the Notary Position Law and SKMHT formal requirements that must be made in an authentic deed based on Article 15 of the Law. Mortgage Rights, so that the result of the deed becomes null and void by continuing to give the right to the injured party to demand compensation from the Notary who has harmed the party.

\section{Conclusion}

Not signing the Minuta SKMHT Deed by the Notary until death has violated the formal requirements of an authentic deed based on the Notary Position Law and the SKMHT formal requirements that must be made in an authentic deed based on Article 15 of the Mortgage Rights Law, so that it is null and void by continuing to provide the right to the aggrieved parties to claim compensation from the Notary who has harmed the party.

\section{References}

Adjie, Habib. (2008). Hukum notaris Indonesia. RefikaAditama.

Adjie, Habib. (2009). Hukum notaris Indonesia tafsir temantik terhadap UU No.30 Tahun 2004 Tentang Jabatan Notaris. RefikaAditama.

Harsono, Boedi. (2005). Hukum agraria Indonesia sejarah pembentukan Undang-Undang Pokok Agraria, isi dan pelaksanaannya jilid 1 hukum tanah nasional (10th ed.). Djambatan.

Khairunnisa, Amira., Kashadi., \& Adhi, Yuli Prasetyo. (2013). Perjanjian Kredit Dengan Surat Kuasa Membebankan Hak Tanggungan (SKMHT) Yang Berakhir Jangka Waktunya Di Perusahaan Daerah Bank Perkreditan Rakyat Kendali Artha Kabupaten Kendal. Diponegoro Law Jaournal, 2(2), 1-12.

Kie, Tan Thong. (2007). Studi notariat \& serba serbi praktik notaries. IchtiarBaru Van Hoeve.

Kohar, A. (1983). Notaris dalam praktek hukum. Penerbit Alumni.

Muljadi, Kartini \& Widjaja, Gunawan. (2005). Hak tanggungan. Kencana Prenada Media Group.

Rustam, Riky. (2017). Hukum jaminan. UII Press.

Rumi Suwardiyati. (2017). Tanggung Jawab Perdata Notaris Atas Akta Antidatir. Hukum Legal Spirit, 1(2), 53-68. https://doi.org/10.31328/ls.v1i2.587

Salim HS. (2004). Perkembangan hukum jaminan di Indonesia. PT. Raja Grafindo Persada.

Satrio, J. (1997). Hukum jaminan, hakjaminan kebendaan, hak tanggungan, bukusatu. PT. Citra Aditya Bakti.

Subekti. (1984). Hukum Perjanjian (9th ed). Ctk. PT. Intermasa.

Sutedi, Adrian. (2010). Hukum hak tanggungan. Sinar Grafika.

Soekanto, Soerjono \& Mahmudji, Sri. (2003). Penelitian hukum normatif: Suatu tinjauan singkat. Raja grafindo Persada.

Usman, Rahmadi. (2018). Kewenangan Notaris Dalam Membuat Surat Kuasa Membebankan Hak Tanggungan Dengan Akta, Jurnal Legislasi Indonesia, 15(3), 223-235. 
Wiguna, Made Oka Cahyadi. (2017). Surat Kuasa Membebankan Hak Tanggungan dan Pengaruhnya Terhadap Pemenuhan Asas Publisitas Dalam Proses Pemberian Hak Tanggungan. Jurnal Legislasi Indonesia, 14 (04), 439-446. 